\title{
Comparison Of Physical And Physiological Parameters Of Children Skier And Volleyball Players
}

\author{
Neşe Akpınar Kocakulak *1 (D), Yahya Polat *2 (D), Zuhal Hamurcu *3 (iD), Osman Pepe *2 (iD), \\ Bekir Çoksevim *4 (iD)
}

\begin{abstract}
This study purpose; to compare the athletic performance of the physical and physiological characteristics of the children who are in the age of 10-15 years and who have regular skiing, with the same characteristics of the children of the same age group and who have played volleyball for one year. Work group; ages 10-15 between changing and over a year volleyball playing 24 girls with same age group the and regular ski sport who 15 girl child volunteer participation with created. Methods; volunteers participating in research lengths naked standing with height measuring instrument and body weights were measured with the weighbridge (Premier). Body oil the percentage determination for; measurements were taken from 6 regions with skinfold caliper (Holtain LTD. Crymych U.K.) and body fat percentages were calculated according to Lange formula. Right-left hand gripping forces hand dynamometer (Takei Hand Grip) and FVC, VC, MW values were measured using spirometer (Cosmed, Pony Spirometer Graphic). Measurements of arterial systolic and diastolic blood pressures from the left arm of all volunteers were taken with the blood pressure monitor (Microfile BP-3AS1-2) and recorded in $\mathrm{mmHg}$. Oxymeter saturation of the volunteers was measured using the Oximeter (NBP-40 Handheld). Resting and post-exercise heart rate, flexibility, speed, agility, long jump, endurance were evaluated by appropriate measurement methods. All data obtained from the measurements were evaluated using the Mann-Whitney $U$ test. Significance levels of the difference between the groups were taken as 0.05 . Findings; the body fat percentage (\%) and exercise pulse of the athletes who played volleyball were higher than the skiers $(p=0.002)$. Long jump (anaerobic power), endurance (aerobic power) were found skiers kids higher than volleyball players $(p=0.002, p=0.029)$ and flexibility was higher in children playing volleyball $(p=0,012)$. No difference was found between the two groups in terms of speed, agility, right/left hand claw strength $(p>0$. 05). There was no difference between lung function of the athletes who played volleyball and skiing ( $p>0.05)$. As a result of the special training methods and programs of skiing and volleyball branches while the strength and flexibility characteristics of the volleyball players were improved, it was observed that the strength and durability properties of the skiers were better.
\end{abstract}

\section{Keywords}

Skiing, volleyball, physical and physiological development

${ }^{1}$ Izmir Democracy University, Faculty of Health Sciences, Department of Sport Sciences,35140, Izmir, Turkey

${ }^{2}$ Erciyes University, Faculty of Sport Sciences,Talas/Kayseri

${ }^{3}$ Erciyes University,Faculty of Medicine, Department of Medical Biology, Talas/Kayseri

${ }^{4}$ Erciyes University, Faculty of Medicine, Department of Physiology, Talas/ Kayseri

*Corresponding Author: nese.kocakulak@idu.edu.tr

Manuscript received date: December 18, 2018

Accept Date: December 31, 2018

Published Date: December 31, 2018.

\section{INTRODUCTION}

Besides to body compositions of athletes both in individual and team sports, sports sciences evaluate physical and physiological profiles among intensive research areas. Every healthy person has the ability to move. However, the ability to develop this ability is different. In addition to the structural quality, which determines the extent of development, the support of this feature from a very early age through training, the quality of the training and the nature of the sport branch constitute the basis of the 
increasing sporting success. Physical health acquired during childhood and adolescence is essential for the body to function optimally (1). Physical activity during childhood is an important factor to consider in terms of maintaining normal growth and development (2). Regular physical activity has extremely positive effects on children's bodies and minds. At the same time, is stated that the child gains the habit of using their free time in a positive and beneficial way and contributes to the child's learning capacity, social, emotional and perceptual motor development and physical fitness (3). Skiing is a sport that requires complex and special skills. If the ski is defined simply, after the appropriate costume, equipment and training; flat planks with curved ends attached to the feet and guided bars for guiding and balancing; The hill has a layout which aims to reach frompoint downwards on the abdomen without falling down. One of the most important sports that increases awareness in children is skiing. When skiing, each part of the body should be managed separately and kept under control. The physical awareness of the beginners at an early age is higher than the other children. In addition to physical awareness, their awareness about themselves increases. They self-discover their strengths and weaknesses and learn how to manage them. In contrast to other sports, there is little research on the physical and physiological characteristics of skiers both in the world and in our country (4). Many individual and team sports require a combination of physical, technical, tactical and metal skills. The players have to have many features such as aerobic and anaerobic capacities in order to perform fast, strong and continuous movements. Volleyball players should also have such characteristics. Team sports requires a detailed skill, including physical, technical, mental and tactical aspects. Among them, the physical skills of the players significantly affect the game intelligence and team tactics because ball games require repeated maximum effort. Therefore, players must have physical skills to strengthen their aerobic and anaerobic capacities and to ensure long-term attack and defense efficiency in order to perform fast and hard movements. Such physical skills are very important when playing volleyball (5). Volleyball is an interval sport consisting of short-term load and rest stages. Volleyball also includes sequential, aerobic and anaerobic loading. Therefore, it can be thought that it requires high muscle strength and skill (6). In order for players to perform fast and powerful movements, they must have many physical and physiological features such as aerobic and anaerobic capacities. Volleyball players must also have such characteristicsVolleyball is one of the most popular branches in the world and it is stated that there are more than 800 million people who play volleyball at least once a week. Volleyball sport; short-term exercise periods and "interval", which can be changed with rest, can be defined as a sport (7). The physical and physiological features required by this sport have a very important placesuccess. Sports science, therefore as well as the physiological profile of athletes, body composition, physical and physiological profiles are evaluated among the intensive research areas.

The purpose of this study is; the physical and physiological characteristics of children skiing between 10-15 years of age, the athletic performance of the same age group and the same characteristics of children playing volleyball for a year is to compare.

\section{MATERIALS \& METHODS}

The research between the ages of 10-15 and volleyball for a year 15 skiers who have been skiing in alpine discipline foryear with 24 volleyball children who have been playing participated voluntarily. The physical and physiological capacitiesthe volunteers were evaluated using the following measurement methods. Volunteers participating in research lengths naked standing with height measuring instrument and body weights were measured with the weighbridge (Premier). For determination of body fat percentage; The skinfold caliper (Holtain LTD. Crymych U.K.), which measures the thickness of the subcutaneous fat with thickness between 1-39 mm, it was measured in 6 regions and body fat percentages were calculated according to the Lange formula (8). Right-left hand gripping forces hand dynamometer (Takei Hand Grip) and FVC, VC, MW values were measured using spirometer (Cosmed, Pony Spirometer Graphic). Measurements of arterial systolic and diastolic blood pressures from the left arm of all volunteers were taken with the blood pressure monitor (Microfile BP-3AS1-2) and recorded in mmHg. Oxymeter saturation of the volunteers was measured using the Oximeter (NBP-40 Handheld). Resting and post-exercise heart rate, flexibility, speed, agility, long jump, endurance were evaluated by appropriate measurement methods. $(9,10,11)$.

Statistical Evaluation: All data obtained from the measurements were evaluated statistically using nonparametric test, Mann-Whitney U test. Significance levels of the difference between the groups were taken as 0.05 .

\section{FINDINGS}

Table 1 shows the physical and physiological characteristics of skiers and volleyball players. Physical properties of body fat ratio, volleyball players were significantly higher than skiers $(\mathrm{p}=0.002)$. Physiological characteristics of the heart rate after exercise was found more volleyball players than skiers. No statistically significant difference was found between skiers and volleyball players in terms of resting heart rate, systolic and diastolic blood pressure and oxygen saturation ( $\mathrm{p}>0.05)$.

Table 2 shows the athletic performance values of skiers and volleyball players. Long jump (anaerobic power), endurance (aerobic power) were found skiers kids higher than volleyball players (p.50. 05) and flexibility was higher in children playing 
volleyball (p5.0. 05). No difference was found between the two groups in terms of speed, agility, right/left hand claw strength $(\mathrm{p}>0.05)$.

Table 1. Comparison of physical and physiological characteristics of athletes playing volleyball and skiing.

\begin{tabular}{|l|l|l|l|}
\hline Parameters & $\begin{array}{l}\text { Parameters } \\
\text { Volleyball } \\
\text { Players } \\
(\mathrm{n}=24)\end{array}$ & Skiers & $\mathrm{P}$ and $\mathrm{Z}$ \\
$(\mathrm{n}=15)$ & $12.37 \pm 1.13$ & $12.37 \pm 1.13$ & $\begin{array}{l}\mathrm{p}=0.109 \\
\mathrm{Z}=1.601\end{array}$ \\
\hline $\begin{array}{l}\text { Age (year) } \\
\text { (avg } \pm \mathrm{SS})\end{array}$ & $155.00 \pm 8.93$ & $150.73 \pm 9.75$ & $\begin{array}{l}\mathrm{p}=0.241 \\
\mathrm{Z}=1.172\end{array}$ \\
\hline $\begin{array}{l}\text { Length (cm) } \\
\text { (avg } \pm \text { SS) }\end{array}$ & $42.58 \pm 6.68$ & $41.40 \pm 6.92$ & $\begin{array}{l}\mathrm{p}=0.514 \\
\mathrm{Z}=0.653\end{array}$ \\
\hline $\begin{array}{l}\text { Weight (kg) } \\
\text { (avg } \pm \text { SS) }\end{array}$ & $15.60 \pm 8.83$ & $11.04 \pm 4.28$ & $\begin{array}{l}* \mathrm{p}=0.002 \\
\mathrm{Z}=3.046\end{array}$ \\
\hline $\begin{array}{l}\text { Body Fat Ratio (\%) } \\
\text { (avg } \pm \text { SS) }\end{array}$ & $77.00 \pm 9.72$ & $75.40 \pm 11.59$ & $\begin{array}{l}\mathrm{p}=0.874 \\
\mathrm{Z}=0.159\end{array}$ \\
\hline $\begin{array}{l}\text { Resting Pulse (stroke/min) } \\
\text { (avg } \pm \text { SS) }\end{array}$ & $111.04 \pm 13.33$ & $92.87 \pm 11.83$ & $\begin{array}{l}\mathrm{p}=0.000 \\
\mathrm{Z}=0.029\end{array}$ \\
\hline $\begin{array}{l}\text { Exercise Pulse (stroke/min) } \\
\text { (avg } \pm \text { SS) }\end{array}$ & $110.46 \pm 16.28$ & $110.33 \pm 17.06$ & $\begin{array}{l}\mathrm{p}=0.977 \\
\mathrm{Z}=0.029\end{array}$ \\
\hline $\begin{array}{l}\text { Systolic Blood Pressure (mmhg) } \\
\text { (avg } \pm \text { SS) }\end{array}$ & $74.79 \pm 12.01$ & $68.47 \pm 17.06$ & $\begin{array}{l}\mathrm{p}=0.080 \\
\mathrm{Z}=1.750\end{array}$ \\
\hline $\begin{array}{l}\text { Diastolic Blood Pressure (mmhg) } \\
\text { (avg } \pm \text { SS) }\end{array}$ & $97.75 \pm 1.26$ & $97.93 \pm 0.80$ & $\begin{array}{l}\mathrm{p}=0.603 \\
\mathrm{Z}=0.520\end{array}$ \\
\hline $\begin{array}{l}\text { Oxygen Saturated (\%) } \\
\text { (avg } \pm \text { SS) }\end{array}$ & &
\end{tabular}

Mann Whitney U test $/ * \mathrm{p}<0.05$

*Body fat percentage and exercise rate of volleyball players were found higher than skiers $(\mathrm{p}=0.002)$.

Table 2. Comparison of athletic performance values of volleyball players and skiers.

\begin{tabular}{|l|l|l|l|}
\hline Parameters & Volleyball Players $(\mathrm{n}=24)$ & Skiers $(\mathrm{n}=15)$ & $\mathrm{P}$ and $\mathrm{Z}$ Values \\
\hline $\begin{array}{l}\text { Flexibility }(\mathrm{CM}) \\
\text { (avg. Tss) }\end{array}$ & $22.58 \pm 5.27$ & $18.13 \pm 4.21$ & $\begin{array}{l}* \mathrm{p}=0.012 \\
\mathrm{Z}=0.517\end{array}$ \\
\hline $\begin{array}{l}\text { Speed 50 m } \\
\text { (avg. Tss) }\end{array}$ & $10.14 \pm 0.64$ & $10.18 \pm 0.62$ & $\begin{array}{l}\mathrm{p}=0.618 \\
\mathrm{Z}=0.505\end{array}$ \\
\hline $\begin{array}{l}\text { Agility } \\
\text { (avg. Tss) }\end{array}$ & $3.86 \pm 1.45$ & $3.81 \pm 0.83$ & $\begin{array}{l}\mathrm{p}=0.977 \\
\mathrm{Z}=0.029\end{array}$ \\
\hline Long Jump (cm) (On.Tss) & $134.04 \pm 9.97$ & $143.73 \pm 42.27$ & $\begin{array}{l}\mathrm{p}=0.002 \\
\mathrm{Z}=3.092\end{array}$ \\
\hline Right Grip (KgW) (avg. $\pm \mathrm{SS})$ & $8.85 \pm 3.80$ & $8.53 \pm 3.36$ & $\begin{array}{l}* \mathrm{p}=0.165 \\
\mathrm{Z}=1390\end{array}$ \\
\hline Left Grip (KgW) (avg. $\pm \mathrm{SS})$ & $7.26 \pm 4.07$ & $8.53 \pm 3.36$ & $\begin{array}{l}\mathrm{p}=0.200 \\
\mathrm{Z}=1.282\end{array}$ \\
\hline $\begin{array}{l}\text { Durability } \\
\text { (avg. Tss) }\end{array}$ & $1566.67 \pm 502.75$ & $1973.33 \pm 481.76$ & $\begin{array}{l}* \mathrm{p}=0.029 \\
\mathrm{Z}=2.181\end{array}$ \\
\hline
\end{tabular}

Mann Whitney U test $/ * \mathrm{p}<0.05<0.05$

*It was found that volleyball players were more flexible than skiers

and skiers had better aerobic and anaerobic capacity than volleyball players. 
Table 3. Comparison of lung function of athletes playing volleyball and skiing.

\begin{tabular}{|l|l|l|l|}
\hline Parameters & $\begin{array}{l}\text { Parameters } \\
\text { Volleyball } \\
\text { Players } \\
(\mathrm{n}=24)\end{array}$ & Skiers & P and $\mathrm{Z}$ \\
$(\mathrm{n}=15)$ & $2.74 \pm 0.61$ & $2.60 \pm 0.52$ & $\begin{array}{l}\mathrm{p}=0.279 \\
\mathrm{Z}=1.083\end{array}$ \\
\hline $\begin{array}{l}\text { FVC } \\
\text { (avg } \pm \text { SS) }\end{array}$ & $2.45 \pm 0.55$ & $2.48 \pm 11.83$ & $\begin{array}{l}\mathrm{p}=0.809 \\
\mathrm{Z}=0.462\end{array}$ \\
\hline $\begin{array}{l}\text { VC } \\
(\text { avg } \pm \text { SS) }\end{array}$ & $79.94 \pm 21.74$ & $79.11 \pm 16.75$ & $\begin{array}{l}\mathrm{p}=0.658 \\
\mathrm{Z}=0.462\end{array}$ \\
\hline MW(avg \pm SS) & $23.58 \pm 5.71$ & $27.67 \pm 5.12$ & $\begin{array}{l}\mathrm{p}=0.066 \\
\mathrm{Z}=1.839\end{array}$ \\
\hline $\begin{array}{l}\text { Anaerobic Power } \\
\text { (avg } \pm \text { SS) }\end{array}$ & 2 & \multicolumn{2}{|c}{} \\
\hline
\end{tabular}

\section{Results}

Regular physical activity from childhood, making exercise an indispensable part of daily life, increasing the amount of daily physical activity over time is very important in protecting individual health and reducing the health risks to be encounteredold age (12). Motor development is parallel to the development of physical growth and central nervous system. It is a process that starts before birth and continues throughout life and is fundamental to physical activity. Physical activity is the most important issue to be considered in the growth process of children. However, it is well known that today's children do less physical activity than recommended (13). In our study, there was no difference in body weight between the two groups, while body fat ratio was higher in volleyball players than in skiers. Body weight and body fat percentages of basketball players and volleyball players were compared, there was no difference in body weight between the two groups, while body fat percentage was found to be higher in volleyball players (14). While all information is in parallel with each other, body fat content in volleyball players is high in the restricted movement area, rest periods are longer according to the branches, and the body fat rate is thought to be high because the used energy sources do not allow the use of fat.

It is stated that the heart rate is higher in volleyball players after exercise and it is stated that the pulse, which is an important indicator of physical adaptation, is not better in volleyball players than in skiers.

In the literature comparing volleyball and handball players, volleyball players are reported to have higher flexibility levels (15). Flexibility of volleyball players; volleyball game, rust, service throw, the ball to the opponent area, the need for flexibility, such as the ability to place the defense is due to the need. It is believed that the speed provided by a static balance on skiing affects the flexible capability. In our studies, volleyball players were found to be more flexible than skiers.

In our study, the strength test showing the anaerobic power with long jump and aerobic strength was found higher in skiers than in volleyball players. The success of some skiers in the alpine discipline and their aerobic capacities have shown a strong relationship between the training and the necessary energy during the race is met with a great deal of aerobic capacity (15). Although aerobic power is important in alpine discipline, it is stated that it does not distinguish between skiers at various levels and it is important in skiing in anaerobic power $(16,17)$. In our findings, the high level of aerobic and anaerobic capacityskiers according to volleyball players is in parallel with the literature findings.

As a result of the special training methods and programs of the skiing and volleyball branches, the quick strength and flexibility characteristics of the volleyball players were improved and the strength and durability of the skiers were better.

\section{References}

1.Baltacı, G. Çocuk ve Spor. Klasman Matbaacılık, Sağlık Bakanlığı, Yayın no:730, 2008.Ankara.

2.Erceg, M., Zagorac, N., Katic, R.The impact of football training on motor development in male children. Coll Antropol, 32: 241-7, 2008.

3. Abigail. F., John, J., Loise, A., Colette, M.Fundamental movement skills and habitual physical activity in young children

4. Neumary G, Hoemagl H, Pfister R ve ark. Physical and physiological factors associated with success in professional alpine skiing. International Journal of Sports Medicine, 24: 571-575, 2003. 
5. Sozen, H.The effect of volleyball training on the physical fitness of high school students Procedia - Social and Behavioral Sciences, 46, 1455 - 1460, 2012.

6.Tsunawake, N., Tahara, Y., Moji, K. Body composition and physical fitness of female volleyball and basketball players of the japan inter-high school championship teams. J Physiol Anthropol Appl Numan Sci, 22,195-20,2003.

7.Abreu, T., Almeidal, D., Soaresll, EA. Nutritional and anthoropometric profile of adolescent volleyball athletes. Revista Brasileria de Medicina do Esporte, 9:4, 2003.

8.Smith DJ, Roberts D, Watson B. Physical, pysiological and performance differences between Canadian national team and universiade volleyball players. Journal of Sports Science, 10: 131-8, 1992.

9.Zorba, E., Ziyagil, MA. Vücut kompozisyonu ve ölçüm metotlan. Sayfa: 299, Erek Ofset, Trabzon, 1995. 10. Smith N., J. Sports Medicine: Health care for young athletes. sayfa: 32-74, 1983.

11.Tamer, K. Sporda fiziksel-fizyolojik perforrnansın ölçülmesi ve değerlendirilmesi Bağırgan yayınevi-Ankara, sayfa: 27154,2000

12. Cicioğlu, 1., Günay, M., Gökdemir, K. Farklı branşlardaki elit bayan sporcuların fiziksel ve fizyolojik parametrelerinin karşılaştırılması. Gazi Beden Eğitimi ve Spor Bilimleri Dergisi 3: 9-16,1998.

13.Toivo, J., Growth, J. J. (2000 ) Physical activity, and motor development in prepubertal children, CRC Pres, 51-55.

14.Tsunawake, N., Tahara ,Y., Moji, K et al. Body composition and physical fitness of female volleyball and basketball players of the japan interhigh school championship teams. J Physiol Anthropol Appl Human Sci, 22: 195-201,2003.

15.White,A.T., Johnson, S.C. Physiological aspects and injury in elite Alpine skiers. Sports Med, 15: 170-8, 1993.

16.Maffiuletti, N.A., Impellizzeri, F., Rampinini, E, et al. Is aerobic power really critical for success in alpine skiing. International Journal of Sports Medicine, 27: 166-167, 2006.

17.Andersen, R.E., Montgomery, D.L. Physiology of alpine skiing. Sports Med, 6: 210-21, 1988 